\title{
Detection of Virulence Genes and Biofilm Forming Capacity of Diarrheagenic E. coli Isolated from Different Water Sources
}

\author{
Sadaf Tariq $^{1}$, Sobia Tabassum ${ }^{2, *}$, Sadia Aslam ${ }^{3}$, Mika Sillanpaa ${ }^{4,5}$, , Wahidah H. Al-Qahtani ${ }^{6}$ \\ and Shafaqat Ali $7,8, *$ (D)
}

1 Department of Biochemistry, Government College University Faisalabad, Faisalabad 38000, Pakistan; sadaftariq787@gmail.com

2 Department of Biological Sciences, International Islamic University, H-10 Campus, Islamabad 44000, Pakistan

3 Department of Botany, Government College University Faisalabad, Faisalabad 38000, Pakistan; sadiaaslam646@gmail.com

4 Department of Chemical Engineering, School of Mining, Metallurgy and Chemical Engineering, University of Johannesburg, P. O. Box 17011, Doornfontein 2028, South Africa; mikaesillanpaa@gmail.com

5 Department of Biological and Chemical Engineering, Aarhus University, Nørrebrogade 44, 8000 Aarhus, Denmark

6 Department of Food Sciences \& Nutrition, College of Food \& Agriculture Sciences, King Saud University, Riyadh 11451, Saudi Arabia; wahida@ksu.edu.sa

7 Department of Environmental Sciences and Engineering, Government College University, Allama Iqbal Road, Faisalabad 38000, Pakistan

8 Department of Biological Sciences and Technology, China Medical University, Taichung 40402, Taiwan

* Correspondence: sobia.tabasum@iiu.edu.pk (S.T.); shafaqataligill@yahoo.com (S.A.)

Citation: Tariq, S.; Tabassum, S.; Aslam, S.; Sillanpaa, M.; Al-Qahtani, W.H.; Ali, S. Detection of Virulence Genes and Biofilm Forming Capacity of Diarrheagenic E. coli Isolated from Different Water Sources. Coatings 2021, 11, 1544. https://doi.org/ 10.3390/coatings11121544

Academic Editor: Teen-Hang Meen

Received: 17 November 2021 Accepted: 8 December 2021 Published: 16 December 2021

Publisher's Note: MDPI stays neutral with regard to jurisdictional claims in published maps and institutional affiliations.

Copyright: (c) 2021 by the authors. Licensee MDPI, Basel, Switzerland. This article is an open access article distributed under the terms and conditions of the Creative Commons Attribution (CC BY) license (https:/ / creativecommons.org/licenses/by/ $4.0 /)$.

\begin{abstract}
Diarrheagenic Escherichia coli (DEC) are associated with frequent incidences of waterborne infections and pose health risk to individuals who contact water for domestic or recreational uses. Detection of DEC pathotypes in drinking water can be used as an indicator of fecal contamination. This study aimed to investigate the occurrence of DEC pathotypes and their capacity to form biofilms in drinking water samples collected from different water sources. In this study, PCR analysis was used to determine the occurrence of four clinically significant virulence genes of diarrheagenic E. coli, eaeA (Enteropathogenic E. coli), stx1, stx2 (Enterohemorrhagic E. coli) and sth (Enterotoxigenic E. coli), in drinking water samples $(n=35)$ by using specific primers and conditions. PCR amplicons were visualized by using agarose gel electrophoresis. A total of $12 / 35(34 \%)$ samples were detected as positive for at least one of the four DEC virulence genes and 11/12 (91\%) E. coli isolates harbored virulence gene while $1 / 12(8 \%) E$. coli isolates harbored none. The eaeA and sth genes were the most detected genes (75\%), while st 1 and st 2 genes were least detected genes $(66 \%)$. Biofilm assay confirmed that ETEC pathotypes can cause damage in enteric walls by attaching and effacing to persist diarrheal conditions. This study indicated that drinking water of different sources is contaminated with potential DEC pathotypes and it can be a source of diarrheal diseases. The amplification of four virulence genes associated with DEC pathotypes (EPEC, EHEC and ETEC) in drinking water demonstrates that potentially virulent DEC pathotypes are distributed in water sources and may be a cause of health concern. There is, therefore, an urgent need to monitor DEC pathotypes in drinking water.
\end{abstract}

Keywords: diarrheagenic E. coli; virulence genes; contamination; pathotypes; isolates; water

\section{Introduction}

In order to ensure good health, the availability of safe and good quality water is very essential [1]. Waterborne infections are major cause of high morbidity and mortality rate and have become a public health problem [2]. In developing countries, ground water is the sole elementary source of drinking water supply, which may contain several pathogens, viruses, bacteria and protozoa, causing 2.5 million deaths from enteric diarrheal diseases 
annually [3,4]. Diarrheal and other gastrointestinal illnesses are common infections among infants and children in developing countries [5]. Improper sanitation and hygiene cause comparatively greater health risk [6,7]. Escherichia coli are one of inhabitants of gut flora and most commonly used indicator for fecal contamination in different drinking water distribution systems [8]. E. coli can survive in drinking water for 4 to 12 weeks, depending upon various environmental factors. According to its biological significance, E. coli live safely in the intestine as harmless commensal [9] and pathogenic strains of bacteria cause intestinal and extra-intestinal infections both in healthy and immunocompromised individuals $[2,10]$.

The accessory genome expresses pathogenic traits that are developed by horizontal gene transfer. The virulence genes are located on the accessory genome: a kind of genome plasticity formed by gain and loss of genetic information [1,11]. On the basis of virulence determinants (acquired), specific combinations and horizontal gene transfer, diarrheagenic E. coli pathotypes are classified into different pathotypes. These pathotypes are enteropathogenic E. coli (EPEC), enteroinvasive E. coli (EIEC), enterohemorrhagic E. coli (EHEC), enteroaggregative E. coli (EAEC), diffusely adherent E. coli (DAEC) and enterotoxigenic E. coli (ETEC) [11,12]. These pathotypes define different clinical features, phenotypic traits, epidemiological evidences and specific virulence factors of DEC pathotypes. These pathotypes vary for their clinical, epidemiological and pathogenic significance [2] (Table 1).

Table 1. Clinical manifestation, intestinal pathology and epidemiological features of epidemics caused by five basic pathotypes of diarrheagenic E. coli.

\begin{tabular}{|c|c|c|c|}
\hline Pathotype & $\begin{array}{l}\text { Clinical Man- } \\
\text { ifestation }\end{array}$ & Pathology & Susceptible Population \\
\hline ETEC & $\begin{array}{l}\text { Watery } \\
\text { diarrhea }\end{array}$ & Not any definite change & $\begin{array}{c}\text { Children in developing } \\
\text { areas, travelers to } \\
\text { risky areas }\end{array}$ \\
\hline EIEC & $\begin{array}{l}\text { Bacillary } \\
\text { diarrhea }\end{array}$ & $\begin{array}{l}\text { Disrupted mucosa with } \\
\text { inflammation of large intestine }\end{array}$ & $\begin{array}{l}\text { Common in developing } \\
\text { countries, affect all ages }\end{array}$ \\
\hline EPEC & Gastroentritis & Attaching and effacing lesions & $\begin{array}{l}\text { Infants and travelers to } \\
\text { risky areas }\end{array}$ \\
\hline EHEC & $\begin{array}{l}\text { Bloody } \\
\text { diarrhea }\end{array}$ & $\begin{array}{c}\text { Attaching and effacing lesions } \\
\text { in intestine followed } \\
\text { by necrosis }\end{array}$ & $\begin{array}{c}\text { Inhabitants of } \\
\text { industrialized areas }\end{array}$ \\
\hline EAEC & $\begin{array}{l}\text { Persistent } \\
\text { diarrhea }\end{array}$ & $\begin{array}{l}\text { Inflammatory responses in } \\
\text { intestine, cytotoxicity } \\
\text { of enterocytes }\end{array}$ & $\begin{array}{l}\text { Children in developing } \\
\text { areas and travelers to } \\
\text { those areas }\end{array}$ \\
\hline
\end{tabular}

DEC pathotypes form colonies on the epithelia of intestines by either inhabiting and invading the intestinal cells. They are specialized to form adhesions on the epithelia and known for their attaching and effacing ability to form lesions [9]. They possess resistance against immune system as the colonies target and respond in a similar manner. The virulence factors inject themselves in the cells by mimicking the cell ligands and disrupt plasticity of cytoskeleton [13], thereby reducing endocytic trafficking; they make themselves resistant to phagocytosis. The host cells respond and defend by inducing inflammatory reactions. It changes the intestinal fluid balance to excrete unwanted and harmful bacteria that cause diarrhea $[14,15]$. The extent of infection depends on the interaction between the cell and bacteria and also on the defense system [16-18].

DEC pathotypes have developed important structures for attaching and effacing the cells such as bundle forming pili ( $b f p)$, EspA filaments and $E A F$ shiga-like toxins and intimin $[19,20]$. The $b f p$ encoded by a $\sim 80 \mathrm{~kb}$ adherence factor forms bacterial micro-colonies. Shiga-like toxin and intimin are encoded by stx and eaeA genes, respectively. The eaeA gene is an E. coli outer membrane protein. Intimin is known for its intimate adhesions. EHEC are shiga toxin producers posessing two main classes: $s t x 1$ and stx2; they are further divided 
into many subtypes $[20,21]$. STEC detection methods mostly depend on serotype $0157 \mathrm{H} 7$. The EPEC secreted proteins are translocated through a type III secretion system [16,22]. It forms a pore inside the bacterial membrane. EspA filaments are parts of type III secretion system [23] and directly related to the epithelial cells due to its interaction in a manner functioning as adhesions $[17,24]$. EAF is important for its role in pathogenicity, biofilm production and colonization. EspA forms a filament-like translocation tube outside the bacteria [25], while $E s p B$ and $E s p D$ are incorporated inside the membrane of host cells [26]. It allows the movement of other proteins through the cell membrane, e.g., Tir an effector protein [23].

The presence of DEC pathotypes forming biofilms can cause a serious threat because it can cause difficulties in medical treatments $[27,28]$. DEC pathotypes, especially ETEC, either make biofilms or attach to already existing biofilms. Biofilms are bacterial surface groups surrounded by extracellular matrix [29,30]. It provides bacteria with shelter, prevents its desiccation, make it resistant to antibiotics and protects it from bacteriophages. Biofilms are rapidly developed on both abiotic and biotic surfaces that are in direct contact with water $[18,27]$. Bacterial biofilm production is highly complex and regulated. They have evolved a complex system of DNA, exopolysaccharides and proteins to protect themselves from environmental stress [31,32]. In developing countries, very few studies have been performed with respect to reporting the virulence genes of DEC isolated from drinking water. Therefore, this study aimed to detect virulence-associated genes of DEC pathotypes associated with human pathology and to assess their ability to form biofilms to determine the risk of drinking contaminated water.

\section{Material and Method}

\subsection{Water Samples Collection}

Drinking water samples were collected from different water sources: ten samples were collected from tank water, five samples were collected from industries, five samples were infused water, three samples were collected from standing water areas, five samples were collected from wells and seven samples were collected from tap labeled as 1-35, respectively. A total of 35 drinking water samples were collected for this study. An amount of $200 \mathrm{~mL}$ of drinking water sample was collected from each site in sterilized glass containers having lids according to the American Public Health Association 2001. These samples were transported to laboratory in a cooler and processed in $4 \mathrm{~h}$.

\subsection{Isolation and Biochemical Identification of E. coli}

The collected samples were cultured on MacConkey agar (Oxoid) plates by swabbing sterilized cotton swab and incubated at $37^{\circ} \mathrm{C}$ for $24 \mathrm{~h}$. These plates were observed to detect grown bacterial colonies. Only suspected colonies were considered for Gram's reaction. Gram-negative bacillus colonies were detected. Each suspected sample was subjected to further biochemical testing. Triple Sugar Iron agar (TSI) test was used for biochemical characterization. The autoclaved TSI agar was allowed to set in a slanted position in sterilized test tubes. The slants were inoculated by picking a colony from the MacConkey agar plates and kept in an incubator at $37^{\circ} \mathrm{C}$ overnight.

\subsection{Extraction of DNA}

The boiling centrifugation method was used to extract DNA from all isolated E. coli colonies as described by [33], with slight modifications. Isolated E. coli colonies were subcultured on nutrient agar at $37^{\circ} \mathrm{C}$. Isolated E. coli colonies were picked from a nutrient agar plate in a sterile Eppendorf tube and washed with $1 \mathrm{~mL}$ sterile normal saline (NS). It was centrifuged at 10,000 rev/ $\mathrm{min}$ for $2 \mathrm{~min}$. The pellet was recovered and re-suspended in $100 \mu \mathrm{L}$ distilled water. Then, the tubes were boiled at $85^{\circ} \mathrm{C}$ for $10 \mathrm{~min}$. The lysate was centrifuged at 13,000 rev/min for $5 \mathrm{~min}$. The supernatant containing template DNA stock was stored at $20^{\circ} \mathrm{C}$. The presence and concentration of extracted template DNA were 
measured by using agarose gel electrophoresis in the sample, and it was compared with a specific DNA marker of known concentration.

\subsection{Polymerase Chain Reaction (PCR)}

PCR (Thermal cycle, London, UK) was performed for the detection of target genes st $x 1$ and st $x 2$ for EHEC, sth for ETEC and eaeA for EPEC by using specific primers (Table 2). The reagents used for each reaction in volumes of $25 \mu \mathrm{L}$ were as follows: $7 \mu \mathrm{L}$ syringe water, $2.5 \mu \mathrm{L} 100 \mathrm{mM} \mathrm{KCl}, 3 \mu \mathrm{L} 3 \mathrm{mM}$ MgCl2, $1 \mu \mathrm{L} 400 \mu \mathrm{M}$ dNTPs, $2.5 \mu \mathrm{L} 20 \mathrm{mM}$ tris-HCl, $0.5 \mu \mathrm{L}$ forward primer, $0.5 \mu \mathrm{L}$ reverse primer, $2.5 \mu \mathrm{L} 0.1 \%$ gelatin, $5.0 \mu \mathrm{L}$ DNA (Template DNA) and $0.5 \mu \mathrm{L} 2.5$ units Taq Polymerase. The PCR mixture was subjected to an initial denaturation step at $95{ }^{\circ} \mathrm{C}$ for $5 \mathrm{~min}$, followed by 35 cycles of denaturation at $95^{\circ} \mathrm{C}$ for $45 \mathrm{~s}$, primer annealing at $57^{\circ} \mathrm{C}$ for $45 \mathrm{~s}$, extension at $72{ }^{\circ} \mathrm{C}$ for $45 \mathrm{~s}$ and the final extension at $72{ }^{\circ} \mathrm{C}$ for $10 \mathrm{~min}$.

Table 2. Primers used in study.

\begin{tabular}{|c|c|c|c|c|}
\hline Pathotype & Target Gene & $\begin{array}{l}\text { Primer Sequence } \\
\qquad\left(5^{\prime}-3^{\prime}\right)\end{array}$ & Size of Product $(\mathbf{k b})$ & References \\
\hline EHEC & stx 1 & $\begin{array}{l}\text { F:ACTTCTCGACTGCAAAGACGTATG } \\
\text { R:ACAAATTATCCCCTGAGCCACTATC }\end{array}$ & 132 & {$[34]$} \\
\hline EHEC & stx 2 & $\begin{array}{l}\text { F:TTCCGGAATGCAAATCAG TC } \\
\text { R:CGATACTCCGGAAGCACATTG }\end{array}$ & 264 & {$[35]$} \\
\hline EPEC & eaeA & $\begin{array}{c}\text { F:CCGATTCCTCTGGTGACGA } \\
\text { R:CCACGGTTTATCAAACTGATAACG }\end{array}$ & 105 & [36] \\
\hline ETEC & sth & $\begin{array}{c}\text { F:TTCACCTTTCCCTCAGGATG } \\
\text { R:CTATTCATGCTTTCAGGACCA }\end{array}$ & 120 & [36] \\
\hline
\end{tabular}

\subsection{Visualization of PCR Products}

Agarose (2\%) was used to make agarose gel. The casting tray was flooded by $10 \times \mathrm{TBE}$ buffer near the gel surface, and $5 \mu \mathrm{L}$ PCR product of each sample along with DNA dye was loaded into each well. An amount of $3 \mu \mathrm{L}$ of DNA ladder was injected in the first well of casting tray. Gel electrophoresis apparatus was then connected to a power supply of $100 \mathrm{~V} / \mathrm{cm}$ for $30 \mathrm{~min}$. The gel was removed from the holder and visualized by a UV illuminator.

\subsection{Biofilm Assay}

The PCR positive samples were further assayed to check biofilm production qualitatively. In order to assay biofilm formation, $3 \mathrm{~mL}$ of autoclaved Luria Bertani broth was taken in a test tube and incubated overnight at $37^{\circ} \mathrm{C}$ at a $130 \mathrm{rpm}$ shaker. An amount of $3 \mathrm{~mL}$ of LB was poured in each test tube, and three sets were made and they were autoclaved. An amount of $100 \mu \mathrm{L}$ of culture was inoculated into each test tube of triplicate sets. These three sets of test tubes were incubated at $37^{\circ} \mathrm{C}$ for different time intervals, i.e., one set for $24 \mathrm{~h}$, the second set for $48 \mathrm{~h}$ and the third set for $72 \mathrm{~h}$. After $24 \mathrm{~h}$, cultured media were discarded from test tubes and stained with $0.5 \%$ crystal violet dye for $5 \mathrm{~min}$. Each test tube was washed with distilled water. Ninety-five percent ethanol $(4 \mathrm{~mL})$ was used to dissolve the ring formed in test tubes after staining them with $0.5 \%$ crystal violet dye and optical density was measured at $570 \mathrm{~nm}$ of all the three sets of test tubes incubated at $37^{\circ} \mathrm{C}$ for 24,48 and $72 \mathrm{~h}[30,37]$.

\subsection{Statistical Analysis}

Statistical analysis for the prevalence of virulence genes of EPEC, ETEC and EHEC in drinking water samples was performed using Microsoft Excel spreadsheet and the result was presented as a percentage or graph. 


\section{Results and Discussion}

\subsection{Distribution of Isolated Organisms}

All collected water samples $(n=35)$ were screened for the presence of DEC bacteria. Twelve out of thirty-five (34\%) water samples were screened as positive for the presence of DAE; thus, 12 E. coli bacteria samples were isolated from collected drinking water. The distribution of water samples was as follows: $30 \%(3 / 10)$ were from tank water, $20 \%$ $(1 / 5)$ were from industrial water, $20 \%(1 / 5)$ were from infused water, $66 \%(2 / 3)$ were from standing water, $20 \%(1 / 5)$ were from well water and $57 \%(4 / 7)$ were from tap water (Table 3).

Table 3. Virulence genes of E. coli isolates from different water sources.

\begin{tabular}{|c|c|c|c|c|}
\hline Sample & eaeA (EPEC) & stx1 (EHEC) & stx2 (EHEC) & $s t h$ (ETEC) \\
\hline 1 & - & - & - & - \\
\hline 2 & - & - & - & - \\
\hline 3 & - & - & - & - \\
\hline 4 & + & + & + & - \\
\hline 5 & - & + & + & + \\
\hline 6 & - & - & - & - \\
\hline 7 & - & - & - & - \\
\hline 8 & + & + & + & + \\
\hline 9 & - & - & - & - \\
\hline 10 & - & - & - & - \\
\hline 11 & - & - & - & - \\
\hline 12 & + & + & + & + \\
\hline 13 & - & - & - & - \\
\hline 14 & - & - & - & - \\
\hline 15 & - & - & - & - \\
\hline 16 & - & - & - & - \\
\hline 17 & - & - & - & - \\
\hline 18 & - & - & - & - \\
\hline 19 & - & - & - & - \\
\hline 20 & - & - & - & - \\
\hline 21 & + & + & + & + \\
\hline 22 & + & + & + & + \\
\hline 23 & - & - & - & - \\
\hline 24 & - & - & - & - \\
\hline 25 & - & - & - & - \\
\hline 26 & + & - & - & + \\
\hline 27 & - & - & - & - \\
\hline 28 & - & - & - & - \\
\hline 29 & + & + & + & + \\
\hline 30 & - & + & + & - \\
\hline 31 & + & - & - & + \\
\hline 32 & - & - & - & - \\
\hline 33 & - & - & - & - \\
\hline 34 & - & - & - & - \\
\hline 35 & + & - & - & + \\
\hline
\end{tabular}




\subsection{Prevalence of Virulence Genes from E. coli Isolates}

Amongst 35 collected water samples, twelve confirmed E. coli isolates were evaluated for various virulence genes eae $A, s t x 1$, stx 2 and sth. Ninety-one percent (11/12) of the E. coli isolates harbored virulence gene while $8 \%(1 / 12) E$. coli isolates harbored none. The most frequent virulence factor genes were eae $A$ and sth, each of which was detected in $75 \%$ of $E$. coli isolates. In contrast, four virulence genes, including eae $A$, stx 1 , st $x 2$ and sth, were each observed in $41 \%$ of $E$. coli isolates (Table 3). In the current study, the frequencies of virulence genes were as follows: eaeA $(75 \%)$, stx $1(66 \%)$, st $x 2(66 \%)$ and sth $(75 \%)$. These readings showed that the prevalence rate of virulence genes $e a e A$ and sth was very high among DEC pathotypes isolated from drinking water. Therefore, the E. coli strains isolated from drinking water carried the virulence-associated eae $A$ and $s t h$ genes more frequently than compared to stx 1 and stx 2 (Figure 1). In addition, the results of the PCR for the identification of eae A, stx1, stx2 and sth genes are shown in Figure 2.

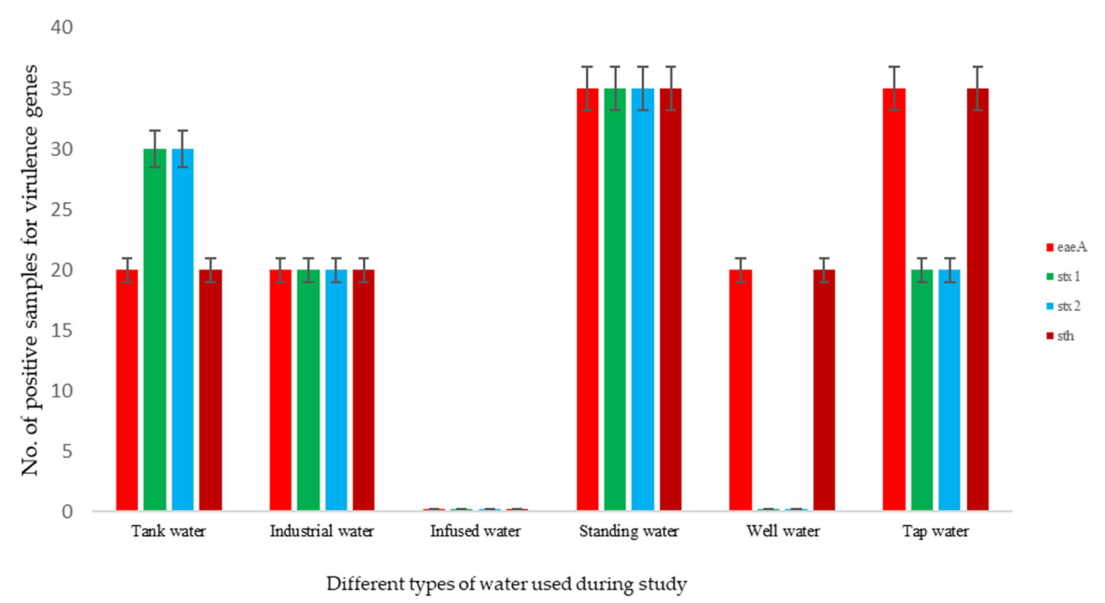

Figure 1. Comparative distribution of virulence genes by individual E. coli isolates.
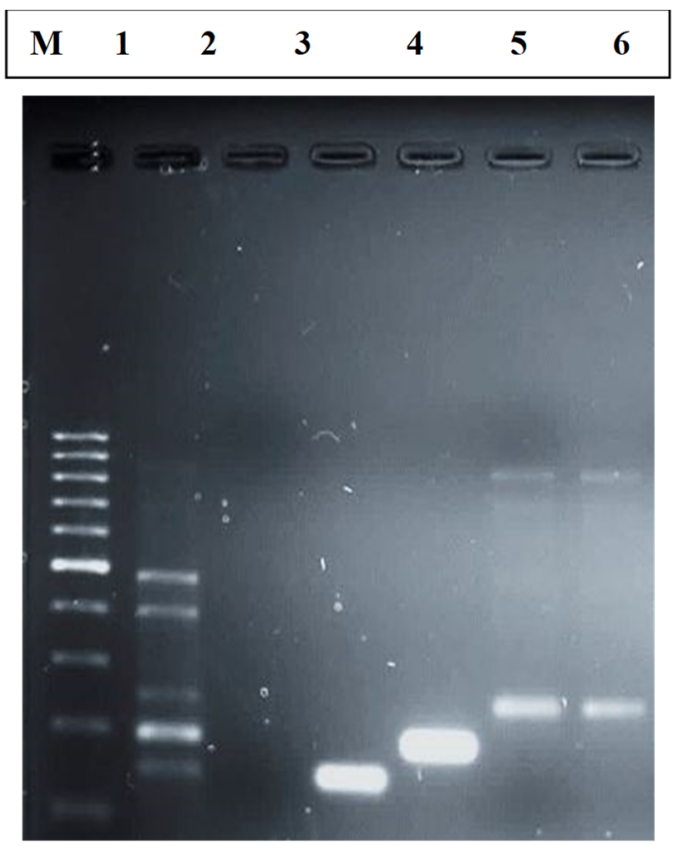

Figure 2. Result of PCR Assay for detection of virulence gene. M: DNA size ladder $1000 \mathrm{bp}$; number 1: positive control; 2: negative control; 3: eaeA; 4: sth; 5: stx1; 6: stx2. 


\subsection{Biofilm Assay}

A biofilm assay was used to check the ability of biofilm production of EPEC, EHEC and ETEC pathotypes. The PCR positive samples were further assayed to check biofilm production. All PCR positive samples were incubated in LB media for different time intervals at $37^{\circ} \mathrm{C}$. Set A of test tubes containing only LB media was taken as control. Three sets of test tubes were prepared; B was incubated for $24 \mathrm{~h}, \mathrm{C}$ was incubated for $48 \mathrm{~h}$ and $\mathrm{D}$ was incubated for $72 \mathrm{~h}$. Zero-point five percent crystal violet dye was used to stain all the test tubes. After staining, the test tubes were washed with distilled water in order to remove excessive dye. The most prominent biofilm ring was observed in the test tube incubated for $24 \mathrm{~h}$ possessing the ETEC pathotype. These strains developed adhesion to the walls of test tubes and formed a ring. The ring formation around the walls of test tubes confirmed biofilm production by ETEC pathotype (Figure 3).
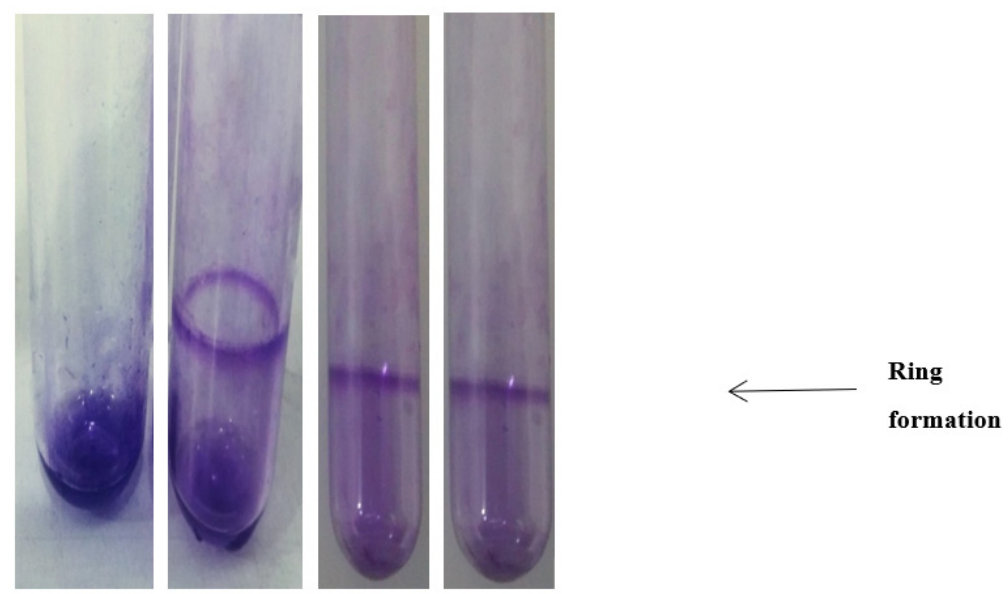

\section{A B C D}

Figure 3. Biofilm assay. (A): Control; (B): E. coli culture inoculated for $24 \mathrm{~h}$; (C): E. coli culture inoculated for $48 \mathrm{~h}$; (D): E. coli inoculated culture for $72 \mathrm{~h}$.

All the samples that showed positive results in the qualitative biofilm assay were further processed in a quantitative biofilm assay. The ring was dissolved by $95 \%$ ethanol, and optical density (OD) was measured in spectrophotometer at $570 \mathrm{~nm}$ (Table 4).

Table 4. Incidence of biofilm formation in each group classified by absorbance.

\begin{tabular}{ccc}
\hline Samples & OD $_{570}$ & Strength of Adhesion \\
\hline 1 & 0.2 & Strongly adherent \\
2 & 0.15 & Moderately adherent \\
3 & 0.1 & Weakly adherent \\
\hline
\end{tabular}

The OD 0.2 of sample 1 reported that these strains can strongly adhere to biotic and abiotic surfaces. Sample 2 producing an OD of 0.15 showed that these strains are also involved in biofilm production with moderate adhesion to the surfaces. Sample 3 with OD 0.1 showed that the strains were involved in weak adhesion to the surfaces with biofilm production as shown by [37]. In current research, virulence genes were detected in DEC isolates to detect the presence of virulent $E$. coli strains in drinking water. Other studies have also reported the presence E. coli strains as fecal indicator bacteria originating from defective hygiene and poor sanitation and animal fecal contact in freshwater places in developing countries $[2,17,38]$. The presence of ETEC in drinking water is indicative of a high risk of contamination. In general, these results found that the risk of contamination may increase over time, and it is high time to follow appropriate preventive measures. 


\section{Conclusions}

Water sources harbor different pathotypes of DEC, which can possibly be suspended by natural or synthetic events. In the present study, four virulence genes (eaeA, stx1, stx2 and $s t h$ ) were investigated pertaining to three DEC pathotypes (EPEC, EHEC and ETEC), which signify a potential health concern for individual drinking water from these sources. Approximately $34 \%$ of analyzed water samples were found positive for at least one of the four virulence genes. The most frequent pathotypes were EPEC and ETEC as eaeA and sth genes were detected in $75 \%$ of pathotypes. The frequencies of pathotypes were as follows: EPEC (75\%), EHEC (66\%) and ETEC (75\%). These findings demonstrated that the rate of prevalence of EPEC and ETEC is very high among DEC pathotypes isolated from drinking water sources. The biofilm assay demonstrated that ETEC pathotypes form adhesions on the walls of test tubes. All ETEC positive samples showed different strength of adhesion from weak to strong. These findings suggest that these four virulence genes are responsible for waterborne infections. This study detected the presence of $E$. coli pathotypes carrying virulence genes isolated from different drinking water samples. Moreover, the biofilm forming capacity of ETEC pathotypes revealed that attaching and effacing ETEC to enteric walls can result in persistent infection. It can cause serious difficulties in medical treatments. In this manner, this study highlights the significance of sanitation and good hygiene in developing countries. Therefore, the detection of virulence genes of E. coli from drinking water directs us to the need to study its origin, reservoir and transmission pathway to create a better preventive and controlling plans. As for public health concern, this data will prove to be a better source for estimating the risk factors related to gastrointestinal infections, and the data will provide a better understanding about public health complications caused by E. coli pathotypes carrying virulence genes. In this study, a set of four virulence genes has been tested and linked to assign the definite pathotypes as a source of human diarrhea. Additional screening of other virulence genes along with serotyping and other assays may provide data on the pathogenicity of DEC isolates.

Author Contributions: Conceptualization, S.T. (Sobia Tabassum) and S.A. (Sadia Aslam); methodology, S.T. (Sadaf Tariq).; software, S.A. (Shafaqat Ali); writing-original draft preparation, S.T. (Sadaf Tariq); writing-review and editing, M.S.; visualization, W.H.A.-Q.; supervision, M.S. All authors have read and agreed to the published version of the manuscript.

Funding: This work was funded by the Researchers Supporting Project Number (RSP-2021/293) King Saud University, Riyadh, Saudi Arabia.

Institutional Review Board Statement: Not applicable.

Informed Consent Statement: Not applicable.

Data Availability Statement: Not applicable.

Conflicts of Interest: The authors declare no conflict of interest.

\section{References}

1. Ahmad, A.; Jini, D.; Aravind, M.; Parvathiraja, C.; Ali, R.; Kiyani, M.Z.; Alothman, A. A novel study on synthesis of egg shell based activated carbon for degradation of methylene blue via photocatalysis. Arab. J. Chem. 2020, 13, 8717-8722. [CrossRef]

2. Aravind, M.; Ahmad, A.; Ahmad, I.; Amalanathan, M.; Naseem, K.; Mary, S.M.M.; Zuber, M. Critical green routing synthesis of silver NPs using jasmine flower extract for biological activities and photocatalytical degradation of methylene blue. J. Environ. Chem. Eng. 2021, 9, 104877. [CrossRef]

3. Pervaiz, M.; Ahmad, I.; Yousaf, M.; Kirn, S.; Munawar, A.; Saeed, Z.; Rashid, A. Synthesis, spectral and antimicrobial studies of amino acid derivative Schiff base metal (Co, Mn, Cu, and Cd) complexes. Spectrochim. Acta Part A Mol. Biomol. Spectrosc. 2019, 206, 642-649. [CrossRef] [PubMed]

4. Hussain, S.; Khan, A.J.; Arshad, M.; Javed, M.S.; Ahmad, A.; Shah, S.S.A.; Qiao, G. Charge storage in binder-free 2D-hexagonal $\mathrm{CoMoO}_{4}$ nanosheets as a redox active material for pseudocapacitors. Ceram. Int. 2021, 47, 8659-8667. [CrossRef]

5. Zhan, M.; Hussain, S.; AlGarni, T.S.; Shah, S.; Liu, J.; Zhang, X.; Liu, G. Facet controlled polyhedral ZIF-8 MOF nanostructures for excellent $\mathrm{NO}_{2}$ gas-sensing applications. Mater. Res. Bull. 2021, 136, 111133. [CrossRef] 
6. Kashif, M.; Ngaini, Z.; Harry, A.V.; Vekariya, R.L.; Ahmad, A.; Zuo, Z.; Alarifi, A. An experimental and DFT study on novel dyes incorporated with natural dyes on titanium dioxide $\left(\mathrm{TiO}_{2}\right)$ towards solar cell application. Appl. Phys. A 2020, 126, 1-13. [CrossRef]

7. Saleem, M.; Irfan, M.; Tabassum, S.; Albaqami, M.D.; Javed, M.S.; Hussain, S.; Zuber, M. Experimental and theoretical study of highly porous lignocellulose assisted metal oxide photoelectrodes for dye-sensitized solar cells. Arab. J. Chem. 2021, $14,102937$. [CrossRef]

8. Kashif, M.; Jaafar, E.; Bhadja, P.; Low, F.W.; Sahari, S.K.; Hussain, S.; Al-Tamrah, S.A. Effect of potassium permanganate on morphological, structural and electro-optical properties of graphene oxide thin films. Arab. J. Chem. 2021, 14, 102953. [CrossRef]

9. Zhang, X.Z.; Xu, P.H.; Liu, G.W.; Ahmad, A.; Chen, X.H.; Zhu, Y.L.; Qiao, G.J. Synthesis, characterization and wettability of Cu-Sn alloy on the Si-implanted 6H-SiC. Coatings 2020, 10, 906. [CrossRef]

10. Fallah, Z.; Zare, E.N.; Ghomi, M.; Ahmadijokani, F.; Amini, M.; Tajbakhsh, M.; Varma, R. Toxicity and remediation of pharmaceuticals and pesticides using metal oxides and carbon nanomaterials. Chemosphere 2021, 275, 130055. [CrossRef]

11. Bibi, S.; Ahmad, A.; Anjum, M.A.R.; Haleem, A.; Siddiq, M.; Shah, S.S.; Al Kahtani, A. Photocatalytic degradation of malachite green and methylene blue over reduced graphene oxide ( $\mathrm{rGO}$ ) based metal oxides $\left(\mathrm{rGO}-\mathrm{Fe}_{3} \mathrm{O}_{4} / \mathrm{TiO}_{2}\right)$ nanocomposite under UV-visible light irradiation. J. Environ. Chem. Eng. 2021, 9, 105580. [CrossRef]

12. Ahmad, I.; Jamal, M.A.; Iftikhar, M.; Ahmad, A.; Hussain, S.; Asghar, H.; Khan, S. Lanthanum-zinc binary oxide nanocomposite with promising heterogeneous catalysis performance for the active conversion of 4-nitrophenol into 4-aminophenol. Coatings 2021, 11, 537. [CrossRef]

13. Javed, M.S.; Khan, A.J.; Ahmad, A.; Siyal, S.H.; Akram, S.; Zhao, G.; Alfakeer, M. Design and fabrication of bimetallic oxide nanonest-like structure/carbon cloth composite electrode for supercapacitors. Ceram. Int. 2021, 47, 30747-30755. [CrossRef]

14. Javed, M.S.; Najim, T.; Hussain, I.; Batool, S.; Idrees, M.; Mehmood, A.; Shah, S.S.A. $2 \mathrm{D} \mathrm{V}_{2} \mathrm{O}_{5}$ ultrathin nanoflakes as a binder-free electrode material for high-performance pseudocapacitor. Ceram. Int. 2021, 47, 25152-25157. [CrossRef]

15. Beena, V.; Rayar, S.L.; Ajitha, S.; Ahmad, A.; Albaqami, M.D.; Alsabar, F.A.A.; Sillanpää, M. Synthesis and characterization of Sr-doped ZnSe nanoparticles for catalytic and biological activities. Water 2021, 13, 2189. [CrossRef]

16. Siyal, S.H.; Javed, M.S.; Ahmad, A.; Sajjad, M.; Batool, S.; Khan, A.J.; Najam, T. Free-standing 3D Co $3 \mathrm{O}_{4} @ \mathrm{NF}$ micro-flowers composed of porous ultra-long nanowires as an advanced cathode material for supercapacitor. Curr. Appl. Phys. 2021, 31, 221-227. [CrossRef]

17. Syah, R.; Ahmad, A.; Davarpanah, A.; Elveny, M.; Ramdan, D.; Albaqami, M.D.; Ouladsmane, M. Incorporation of $\mathrm{Bi}_{2} \mathrm{O}_{3}$ residuals with metallic bi as high performance electrocatalyst toward hydrogen evolution reaction. Catalysts 2021, 11, 1099. [CrossRef]

18. Abbas, Q.; Javed, M.S.; Ahmad, A.; Siyal, S.H.; Asim, I.; Luque, R.; Tighezza, A.M. ZnO nano-flowers assembled on carbon fiber textile for high-performance supercapacitor's electrode. Coatings 2021, 11, 1337. [CrossRef]

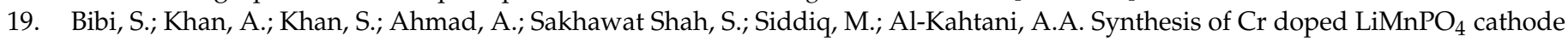
materials and investigation of their dielectric properties. Int. J. Energy Res. 2021. [CrossRef]

20. Raees, A.; Jamal, M.A.; Ahmad, A.; Ahmad, I.; Saeed, M.; Habila, M.A.; Alomar, T.S. Synthesis and characterization of Ceria incorporated Nickel oxide nanocomposite for promising degradation of methylene blue via photocatalysis. Int. J. Environ. Sci. Technol. 2021, 1-8. [CrossRef]

21. Beena, V.; Rayar, S.L.; Ajitha, S.; Ahmad, A.; Iftikhar, F.J.; Abualnaja, K.M.; Ali, S. Photocatalytic dye degradation and biological activities of Cu-doped ZnSe nanoparticles and their insights. Water 2021, 13, 2561. [CrossRef]

22. Mahmud, Z.H.; Kabir, M.H.; Ali, S.; Moniruzzaman, M.; Imran, K.M.; Nafiz, T.N.; Islam, M.S.; Hussain, A.; Hakim, S.A.I.; Worth, M.; et al. Extended-spectrum beta-lactamase-producing Escherichia coli in drinking water samples from a forcibly displaced, densely populated community setting in Bangladesh. Front. Public Health 2020, 8, 228. [CrossRef] [PubMed]

23. Ochien, G.; Atieno, L. Prevalence of Enterotoxigenic Escherichia coli among Children under Five Years in Siaya County, Western Kenya. Master's Thesis, Maseno University, Kisumu, Kenya, 2021.

24. Hassan, A.; Ojo, B.; Abdulrahman, A. Escherichia coli as a global pathogen. Achiev. J. Sci. Res. 2021, 3, $239-260$.

25. Marquezini, M.G.; da Costa, L.H.; Bromberg, R. Occurrence of the seven most common serotypes of Shiga toxin-producing Escherichia coli in beef cuts produced in meat-processing plants in the state of São Paulo, Brazil. J. Food Prot. 2021. [CrossRef] [PubMed]

26. Fonseca, T.G.; Motta, E.A.; Mass, A.P.; Fongaro, G.; Ramos, F.M.; Machado, M.S.; Bocchese, D.C.; Viancelli, A.; Michelon, W. Toxicity and enterobacteriaceae profile in water in different hydrological events: A case from south Brazil. Water Air Soil Pollut. 2021, 232, 1-12. [CrossRef]

27. Bel, J.S.; Khaper, N.; Kurissery, S.; Leung, K.T. A novel comparison of virulence genes, biofilm-forming capacity, antibiotic resistance, and level of reactive oxygen species of sediment, sewage, and O157 E. coli. Water Air Soil Pollut. 2021, 232 , 1-19. [CrossRef]

28. Angulo-Zamudio, U.A.; Gutiérrez-Jiménez, J.; Monroy-Higuera, L.; Flores-Villaseñor, H.; Leon-Sicairos, N.; Velazquez-Roman, J.; Vidal, J.E.; Tapia-Pastrana, G.; Canizalez-Roman, A. Non-diarrheagenic and diarrheagenic E. coli carrying supplementary virulence genes (SVG) are associated with diarrhea in children from Mexico. Microb. Pathog. 2021, 157, 104994. [CrossRef]

29. Ravi, M.; Ngeleka, M.; Kim, S.-H.; Gyles, C.; Berthiaume, F.; Mourez, M.; Middleton, D.; Simko, E. Contribution of AIDA-I to the pathogenicity of a porcine diarrheagenic Escherichia coli and to intestinal colonization through biofilm formation in pigs. Vet. Microbiol. 2007, 120, 308-319. [CrossRef] 
30. Corzo-Ariyama, H.A.; García-Heredia, A.; Heredia, N.; García, S.; León, J.; Jaykus, L.; Solís-Soto, L. Phylogroups, pathotypes, biofilm formation and antimicrobial resistance of Escherichia coli isolates in farms and packing facilities of tomato, jalapeño pepper and cantaloupe from Northern Mexico. Int. J. Food Microbiol. 2019, 290, 96-104. [CrossRef]

31. Safadi, R.A.; Abu-Ali, G.S.; Sloup, R.E.; Rudrik, J.T.; Waters, C.M.; Eaton, K.A.; Manning, S.D. Correlation between in vivo biofilm formation and virulence gene expression in Escherichia coli O104: H4. PLoS ONE 2012, 7, e41628. [CrossRef] [PubMed]

32. Sukkua, K.; Rattanachuay, P.; Sukhumungoon, P. Ex vivo adherence to murine ileal, biofilm formation ability and presence of adherence-associated of human and animal diarrheagenic Escherichia coli. Southeast Asian J. Trop. Med. Public Health 2016, 47, 40.

33. Al-Gallas, N.; Annabi, T.A.; Bahri, O.; Boudabous, A. Isolation and characterization of shiga toxin-producing Escherichia coli from meat and dairy products. Food Microbiol. 2002, 19, 389-398. [CrossRef]

34. Chandran, A.; Mazumder, A. Occurrence of diarrheagenic virulence genes and genetic diversity in Escherichia coli isolates from fecal material of various avian hosts in British Columbia, Canada. Appl. Environ. Microbiol. 2014, 80, 1933-1940. [CrossRef] [PubMed]

35. Huang, S.-W.; Hsu, B.-M.; Su, Y.-J.; Ji, D.-D.; Lin, W.-C.; Chen, J.-L.; Shih, F.-C.; Kao, P.-M.; Chiu, Y.-C. Occurrence of diarrheagenic Escherichia coli genes in raw water of water treatment plants. Environ. Sci. Pollut. Res. 2012, 19, 2776-2783. [CrossRef]

36. Chandran, A.; Mazumder, A. Prevalence of diarrhea-associated virulence genes and genetic diversity in Escherichia coli isolates from fecal material of various animal hosts. Appl. Environ. Microbiol. 2013, 79, 7371-7380. [CrossRef]

37. Wakimoto, N.; Nishi, J.; Sheikh, J.; Nataro, J.P.; Sarantuya, J.; Iwashita, M.; Manago, K.; Tokuda, K.; Yoshinaga, M.; Kawano, Y. Quantitative biofilm assay using a microtiter plate to screen for enteroaggregative Escherichia coli. Am. J. Trop. Med. Hyg. 2004, 71, 687-690. [CrossRef] [PubMed]

38. Moglad, E.H.; Jalil Adam, O.A.E.; Alnosh, M.M.; Altayb, H.N. Retracted: Detection of virulence genes of diarrheagenic Escherichia coli strains from drinking water in Khartoum State. J. Water Health 2020. [CrossRef] 